\title{
A Techno-Efficiency Analysis of Zakat Institutions in Indonesia
}

\author{
Nikmatul Atiya, Tika Widiastuti, Eko Fajar Cahyono, Siti Zulaikha, Imron Mawardi \\ Department of Islamic Economics, Faculty of Economics and Business, Universitas \\ Airlangga
}

\begin{abstract}
Zakat institutions play an important role in managing zakat effectively and efficiently as described in Law no. 23 of year 2011. This study aims to analyze the efficiency of zakat institutions in Indonesia and determine the best ranking of the units observed. This study uses a descriptive quantitative approach with the Super Efficiency Analysis. The study objects are BAZNAS, Rumah Zakat, Dompet Dhuafa, and YBM PLN with the 2016-2018 observation period. Personnel costs, operational costs, and socialization costs are input variables. While the output variables used are the amount of zakat collected and the amount of zakat distributed. The results of super-efficiency measurement show that the 3 best DMU rankings were achieved by YBM PLN 2016, BAZNAS 2018 and BAZNAS 2017. While the other 9 DMUs were inefficient. Inefficiency is due to the not optimal amount of zakat collected and zakat distributed and the high use of socialization costs. The variable of the amount of zakat collected is the most sensitive variable to the value of efficiency. To achieve performance efficiency, technology can be utilized to improve input and output. This research can be used as an evaluation material for zakat institutions to optimize efficiency.
\end{abstract}

Keywords: Super Efficiency; Zakat Institution; Technology

\section{INTRODUCTION}

Zakat is one of the pillars of Islam. One of the orders to pay zakat is mentioned in the Quran Surah Al-Baqarah verse 43 which means "and establish prayers, pay zakat and bow along with those who are rukuk." The essence of paying zakat apart from the assets owned is the part of those who cannot afford it, but it can also improve the quality of faith and cleanse the soul.

Zakat has an economic function, namely ensuring an even distribution of income. Johari et al. (2013) stated that the distribution of zakat is very important in determining the distribution of income. Zakat is an alternative solution to reducing poverty and inequality by distributing zakat to eight ashnaf. Zakat as an economic stimulus through sharing mechanisms and equitable economic growth. The benefits of zakat can be felt more widely if it is managed properly.
Zakat in Indonesia continues to develop. From the collection side, statistical data shows that the amount of zakat and other funds collected continues to increase. In 2019 the collection of Zakat, Infaq, Alms, and other funds reached 8.1 trillion (Puskas BAZNAS, 2020). It can be interpreted that there is an increased awareness of paying zakat and a sense of trust from muzakki to zakat institutions. However, the realization of the collection is still far from potential. The potential for zakat in 2019 reaches 233.84 trillion (Puskas BAZNAS, 2020). The gap between the potential and realization of zakat funds is still far away.

From the distribution side, zakat distributed by zakat institutions can have a positive effect on the recipients. Ali et al. (2016) show that zakat distributed by zakat institutions in consumptive and productive forms can improve the welfare of mustahiq. Furthermore, Nurzaman (2017) found that 
productive zakat that is distributed increases the mustahiq welfare index both in material and spiritual terms. Other research such as those conducted by Sari et al. (2019) and Razak (2020) also show the same result. However, Afriadi and Sanrego (2016) found that overlapping distribution with government programs is one of the priority problems of the Zakat Institution, making distribution less effective and efficient. Zakat institutions as intermediary institutions in the social sector must ensure that zakat is managed effectively and efficiently so that it can provide wider benefits for mustahiq.

During the problems faced, zakat institutions must continue to improve their performance at an efficient. Zakat institutions work efficiently by maximizing output with existing inputs or producing certain outputs with minimal inputs. In working efficiently, in this digital era, the use of technology can be developed. Technology can be used to support performance efficiency (Wahab and Rahman, 2011). The existence of regulations and guidelines such as Law no. 23 of 2011, Zakat Core Principles and other regulations are evidence that apart from being managed effectively, zakat must also be managed efficiently. Adiwijaya and Suprianto (2020) state that efficiency is one of the criteria for good zakat governance. Efficiency is an important element to maintain reputation, trust from the public, and as a material for performance evaluation in the management of zakat. Therefore, it is necessary to measure the efficiency so that zakat management can be optimal.

One measure of the efficiency of zakat institutions is using the method Data Envelopment Analysis (DEA). By using several input and output variables it can be analyzed how efficient the zakat institution is and the optimal solution that can be generated. However, measuring the efficiency of zakat institutions using the method Data Envelopment Analysis (DEA) has a weakness, namely that the efficiency value is limited to 1 or $100 \%$ so that the best efficiency rating and changes in efficiency values are not known. By knowing the level of change in efficiency each year will make it easier for zakat institutions to evaluate performance. Overcoming the weaknesses of the standard DEA model, Andersen and Petersen (1993) developed the concept of Super Efficiency analysis. Super Efficiency is a measure of the power of the efficient units used to determine the observed DMU rating. Super Efficiency Analysis allows the efficiency of the DMU to be more than 1 or $100 \%$.

This study aims to measure and analyze the efficiency of zakat institutions in 2016-2018 using the Super Efficiency. This research is related to research by Wahab et al. (2012), Rusydiana and Al Farisi (2016), Rusydiana and Widiastuti (2018), Rusydiana and Al Farisi (2018), Budiantoro et al. (2018), and Rustyani and Rosyidi (2018) with updates to the Super Efficiency method. This research is expected to be used as an evaluation material not only for the observed zakat institutions but also for all zakat institutions in Indonesia.

\section{LITERATURE REVIEW}

\section{Efficiency Concept}

According to Kamus Besar Bahasa Indonesia (KBBI) it is said to be efficient if something is done properly, it does not waste time, effort, and cost. In Islam, the concept of efficiency is explained in QS. Al-Isra verse 26 which means "And give to families that are close to their rights, to the poor and those who are traveling and do not waste (your wealth) wastefully." According to the Zubdatut Tafsir, it is prohibited to overspend assets even for things that are lawful or to spend assets for things that are haram even if only a little. From these verses and interpretations, efficiency is an action that is not wasteful, and all resources are used appropriately. 
In economics, an organization is said to be efficient when it can produce maximum output with certain inputs or produce certain outputs with minimal inputs. An economy is said to be efficient if all existing resources have been used and produce a flow of goods and services for the needs of many people (Chapra, 1992).

One of the measures of efficiency is the Data Envelopment Analysis (DEA) method. In the Data Envelopment Analysis method, there are two orientations used, namely input oriented and output oriented. The input-oriented shows how much output can be produced with minimal input, while the output oriented shows the maximum output that can be produced with certain input. The difference in the use of this orientation will affect the target recommendation that can be applied to the actual value if there are units that are considered inefficient. In the DEA, there are two assumptions, namely CCR and BCC. DEA-CCR was developed by Charnes et al. (1978) while DEA-BCC was developed by Banker et al. (1984). CRR assumes the unit under study operates on a constant return to scale by assuming that the input will give the same output. Meanwhile, BCC assumes that the unit under study operates with a return to scale (VRS) variable, that is, the use of input can produce smaller or larger output results.

While the basic DEA model can measure different types of efficiency scores, the DEA makes it impossible to know the efficiency unit rating because the efficiency score is 1 or $100 \%$. Andersen and Petersen (1993) then developed a superefficiency model to overcome this deficiency. Super Efficiency allows the measurement of the efficiency with an efficiency value of more than 1 for a unit that is considered efficient so that the best unit of all observed units can be found. Super Efficiency is very useful if we want to evaluate efficiency per year because it is known that the difference value is limited to 1 or $100 \%$.

\section{The Concept of Zakat Institution}

Zakat has great benefits for that zakat must be managed institutionally by Islamic law as described in Law No. 23 of 2011 on Zakat Management. Previously, zakat management in Indonesia has a long history, starting from being managed traditionally to establishing an institution that is tasked with managing zakat. Zakat management in Indonesia by zakat institutions, both those formed by the government and the community. Based on Law no. 23 of 2011 The Zakat Institute has duties in terms of collecting, managing, distributing, and utilizing zakat. The Zakat Institution as an intermediary institution in the social sector has to coordinate the needs of muzakki and mustahiq. On the ashnaf side, the zakat institution is in charge of taking zakat from them. On the mustahiq side, through the management and distribution of zakat, zakat institutions have a big role to play in changing the status of mustahiq to muzakki. In that sense, mustahiq get out of poverty and get prosperity. In realizing welfare, based on Law no. 23 of 2011 states that zakat management must be carried out effectively and efficiently.

Efficiency is an important criterion in the Zakat Institution. Adiwijaya and Suprayitno (2020) stated that the management of zakat institutions is said to be good if it meets the efficiency criteria. It is further explained that efficiency is related to the distribution aspect. If zakat institutions work efficiently, it can be said that the distribution is placed in the right program. In carrying out the management of zakat effectively and efficiently, the Zakat Institution receives a part of the collected funds which are used for operational needs.

The efficiency of the Zakat Institution builds public reputation and trust. Wahid et al. (2009) found that the inefficiency of zakat institutions affects the dissatisfaction of muzakki in entrusting 
zakat pay. In terms of the professionalism of zakat management, one of which is reflected in the efficiency of zakat institutions. To achieve the efficiency of the Zakat Institution, the use of technology can be developed. Wahab and Rahman (2011) stated that technology adoption is important in improving the level of efficiency.

\section{Previous Research}

Several studies discussing the efficiency of zakat institutions, one of which was conducted by Budiantoro et al. (2018) This study measures the efficiency of BAZNAS for the period 2002-2016 using the Stochastic Frontier Analysis (SFA). The input variables used are total assets and operational costs. While the collection of zakat and distribution of zakat are output variables. BAZNAS efficiency level based on the amount of zakat collected is $94.98 \%$. Meanwhile, the BAZNAS efficiency level based on the amount of zakat distribution is $70.99 \%$. From the collection side, there is $5.02 \%$ that must be optimized and $29.01 \%$ from the distribution side that must be optimized.

Rustyani and Rosyidi (2018) measure the efficiency of six zakat institutions, namely LAZ YDSF, LAZ AlAzhar, LAZ ACT, LAZ Rumah Yatim Arrohman Indonesia, LAZ PKPU, and LAZ Rumah Zakat for the 2014-2016 period using Data Envelopment Analysis (DEA). The input variables used are the total zakat collection, total costs, and amil receipts. The output variables used are the amount of distribution of funds and total assets. There are two LAZ that experienced inefficiency in 2014-2015, namely LAZ YDSF and ACT. Meanwhile, in 2016 all zakat institutions achieved optimal efficiency.

Rusydiana and Al Farisi (2016) measure the efficiency of three zakat institutions, namely BAZNAS, PKPU, and Rumah Zakat in the 2007-2014 period using the Data Envelopment Analysis (DEA) method. The output variables used are the amount of zakat collection, the amount of zakat distribution. Meanwhile, operational costs, socialization costs, and personnel costs are input variables. The results show that 12 DMUs operate efficiently and six DMUs experience inefficiency. The main factor of inefficiency is the distribution of zakat funds to ashnaf which is still not optimal.

\section{RESEARCH METHOD}

This research is a quantitative descriptive study using the Super Efficiency-Data Envelopment Analysis (DEA) analysis technique. The population in this study are all zakat institutions in Indonesia, both those managed by the government or the community. The samples used were BAZNAS, LAZ Rumah Zakat, LAZ Dompet Dhuafa, and YBM PLN. The sample selection uses a purposive sampling technique by determining the criteria 1) zakat institutions with the largest acceptance and distribution of zakat funds, 2) publish financial reports on the website from 2016-2018.

Types and sources of data use secondary data obtained from the 20162018 Zakat Institution Annual Financial Statements published on the zakat institution's website. There are 12 DMUs from four zakat institutions and three periods. The measurement of efficiency in this study uses a production approach. In measuring the efficiency using the Super Efficiency DEA, the input and output variables are used. Input variables are personnel costs (X1), socialization costs (X2), and operational costs (X3). While the output variables used are the amount of zakat collected (Y1) and the amount of zakat distributed (Y2).

The operational definitions of the variables in this study are:

1. Personnel costs (X1) are costs for salaries and employee benefits in one year. 
2. Socialization costs (X2) are costs used for socialization, promotion, publication in one year.

3. Operational costs (X3) are the entire use of amil funds except for personnel and socialization costs in one year.

4. The amount of zakat collected (Y1) is the number of zakat funds collected, either obtained from muzakki or profit-sharing.

5. The amount of zakat distributed (Y2) is the amount of zakat that is distributed to ashnaf.

As explained earlier, the efficiency measurement carried out using Super efficiency is the development of Data Envelopment Analysis (DEA). Andersen and Petersen (1993) developed Super Efficiency which allows measurement of DMU efficiency with a value of more than 1 or $100 \%$. Super Efficiency only affects units that are considered efficient with the restrictions removed. Meanwhile, inefficient units are not affected because the efficiency is less than 1. Super Efficiency is used to rank the DMU that is the object of observation.

The data processing stage starts from grouping the types of costs in the financial statements into predetermined variables. Furthermore, data analysis was carried out using the Banxia Frontier Analyst 4 software. The assumptions used were CCR (CRS) with an output orientation. After the data analysis process is complete, a ranking of the DMU is carried out, investigating the causes of inefficiency, and conducting a sensitivity analysis to determine the influencing or sensitive variables in determining the efficiency value.

\section{RESULT}

In this study, the measurement of efficiency is based on the CRR assumption with an output orientation. Output-oriented is chosen in measuring the efficiency of zakat institutions where there are gaps in the realization and potential of zakat. Table 1 shows the standard DEA measurements and the efficiency values given relative, not absolute, efficiency values. The use of Super Efficiency will result in an efficiency score of $\geq 100 \%$ for DMUs that are considered efficient. As with DEA, an efficiency score $<100 \%$ indicates that the DMU is inefficient. Table 1 below describes the super efficiency scores of the 12 DMUs observed using three input variables (personnel costs, operational costs, and socialization costs) and two outputs (the amount of zakat collected and the amount of zakat distributed). Of the 12 DMUs, 3 DMUs showed efficient scores, namely BAZNAS 2017, BAZNAS 2017, and YBM PLN 2016. While the other 9 DMUs experienced inefficiency and needed to make improvements to their inputs or outputs to achieve efficient results.

Table 1. Efficiency Super Value

\begin{tabular}{lcc}
\multicolumn{1}{c}{ DMU } & Score (\%) & Rank \\
\hline BAZNAS_2016 & 62.1 & 9 \\
\hline BAZNAS_2017 & 113 & 3 \\
\hline BAZNAS_2018 & 121.4 & 2 \\
\hline LAZ RZ_2016 & 68.1 & 7 \\
\hline LAZ RZ_2017 & 72.7 & 6 \\
\hline LAZ RZ_2018 & 75.8 & 5 \\
\hline LAZ DD_2016 & 52.8 & 10 \\
\hline LAZ DD_2017 & 47.5 & 11 \\
\hline LAZ DD_2018 & 38.5 & 12 \\
\hline $\begin{array}{l}\text { YBM } \\
\text { PLN_2016 }\end{array}$ & 159.3 & 1 \\
\hline $\begin{array}{l}\text { YBM } \\
\text { PLN_2017 }\end{array}$ & 86.2 & 4 \\
\hline $\begin{array}{l}\text { YBM } \\
\text { PLN_2018 }\end{array}$ & 64.4 & 8 \\
\hline Sour : & & \\
\hline
\end{tabular}

Source: Data Processing Banxia Frontier Analyst 4 (2020)

Seen in the table above, the best ranking of the 12 DMUs observed were 
YBM PLN 2016, then BAZNAS 2018, BAZNAS 2017. Next, YBM PLN 2017, Rumah Zakat 2018, Rumah Zakat 2017, Rumah Zakat 2016, YBM PLN 2018. Followed by BAZNAS 2016, Dompet Dhuafa 2016, Dompet Dhuafa 2017, and Dompet Dhuafa 2018.

If Zakat Institutions experiences inefficiency, it is necessary to make improvements or improvisation on input and output. Table 2 shows potential improvement, namely input and output targets that can be applied to achieve efficient management. Almost all observed
Zakat Institutions must reduce the cost of socialization and increase the amount of zakat collected and the amount of zakat distributed. Meanwhile, the reduction in personnel costs only occurred at BAZNAS 2016, and operational costs reduction at YBM PLN 2017 and 2018. From the potential improvement table below, it can also be seen that the cause of Zakat Institutions inefficiency is the use of large socialization costs but has not been able to produce the same output. Another cause of inefficiency is that the amount of zakat collected, and zakat distributed is still far from the target.

Table 2. Value of Potential Improvement Dompet Dhuafa (\%)

\begin{tabular}{|c|c|c|c|c|c|}
\hline DMU & $\begin{array}{l}\text { Personnel } \\
\text { Cost }\end{array}$ & $\begin{array}{c}\text { Operational } \\
\text { Cost }\end{array}$ & $\begin{array}{c}\text { Socialization } \\
\text { Cost }\end{array}$ & $\begin{array}{c}\text { Zakat } \\
\text { Collected }\end{array}$ & $\begin{array}{c}\text { Zakat } \\
\text { Distributed }\end{array}$ \\
\hline BAZNAS_2016 & -48 & 0 & 0 & 61 & 63 \\
\hline LAZ RZ_2016 & 0 & 0 & -34 & 90 & 46 \\
\hline LAZ RZ_2017 & 0 & 0 & -13 & 86 & 37 \\
\hline LAZ RZ_2018 & 0 & 0 & -28 & 69 & 31 \\
\hline LAZ DD_2016 & 0 & 0 & -62 & 89 & 89 \\
\hline LAZ DD_2017 & 0 & 0 & -63 & 110 & 140 \\
\hline LAZ DD_2018 & 0 & 0 & -63 & 159 & 187 \\
\hline $\begin{array}{l}\text { YBM } \\
\text { PLN_2017 }\end{array}$ & 0 & -16 & -24 & 15 & 19 \\
\hline $\begin{array}{l}\text { YBM } \\
\text { PLN_2018 }\end{array}$ & 0 & -18 & -9 & 55 & 61 \\
\hline
\end{tabular}

Source: Data Processing Banxia Frontier Analyst 4 (2020)

In the super efficiency method, it is possible to measure the sensitivity of each variable. Sensitivity analysis is carried out to determine the difference in efficiency values after measuring the efficiency, which is then done by eliminating one of the variables. If in the next measurement by eliminating one of the variables there is a change in the efficiency value, then the variable is considered sensitive to the efficiency value. This sensitivity analysis affects the final recommendations produced. The measurement of super- efficiency in this study is output-oriented, so the writer will see that the sensitivity analysis is only carried out on the output variable. Previously, the measurement of sensitivity analysis was carried out by (Ruysdiana and Hasib, 2020) with the object of observation of Islamic banking. 
Table 3. Results of Sensitivity Analysis (\%)

\begin{tabular}{cccc}
\hline DMU & $\begin{array}{c}\text { Without } \\
\text { Eliminating } \\
\text { Variable }\end{array}$ & $\begin{array}{c}\text { Without Zakat } \\
\text { Collected }\end{array}$ & $\begin{array}{c}\text { Without Zakat } \\
\text { Distributed }\end{array}$ \\
\hline BAZNAS_2016 & 62.1 & 57.4 & 62.1 \\
\hline BAZNAS_2017 & 113 & 87.7 & 108.6 \\
\hline BAZNAS_2018 & 121.4 & 153.2 & 82.9 \\
\hline LAZ RZ_2016 & 52.8 & 52.3 & 49 \\
\hline LAZ RZ_2017 & 47.5 & 38.7 & 47.5 \\
\hline LAZ RZ_2018 & 38.5 & 32.7 & 38.5 \\
\hline LAZ DD_2016 & 68.1 & 68.1 & 52.3 \\
\hline LAZ DD_2017 & 72.7 & 72.7 & 53.2 \\
\hline LAZ DD_2018 & 75.8 & 75.8 & 58.3 \\
\hline YBM PLN_2016 & 159.3 & 159.3 & 154.3 \\
\hline YBM PLN_2017 & 86.2 & 83.5 & 86.2 \\
\hline YBM PLN_2018 & 64.4 & 62.1 & 64.4 \\
\hline
\end{tabular}

Source: Data Processing Banxia Frontier Analyst 4 (2020)

Based on the measurement of the sensitivity analysis above, the DMU that changes when the output variable amount of zakat collected is omitted, namely 8 DMU. There is a change in the value of efficiency if the variable zakat collected is removed. It can be interpreted that the assessment of efficiency is sensitive to the variable of zakat collected. While analyzing the zakat distributed variable, 7 DMUs experienced changes in value. When compared between the output variables, the most sensitive to the efficiency value is the amount of zakat collected.

\section{DISCUSSION}

Based on Law no. 23 of year 2011 zakat management must be carried out effectively and efficiently. Therefore, it is necessary to measure the efficiency of zakat institutions as an evaluation material so that management is right on target. One method to measure efficiency is Super Efficiency which can give the best rating when the efficiency value is not limited to $100 \%$. The application of the super efficiency method with the object of observation by the Zakat Institute has never been done before. The measurement of efficiency in this study uses the CRS (Constant Return to Scale) assumption, which is a condition where the addition of 1 input will produce the same output. The orientation to the output is used with the assumption that the Zakat Institution has sufficient input to achieve maximum output. Also, there is a gap between zakat potential and realization so that the output orientation is chosen. The measurement results show 3 DMUs with the best ratings, namely YBM PLN 2016, BAZNAS 2018, and BAZNAS 2018. 3 DMUs are DMUs that get efficient results with efficiency values above $100 \%$. Meanwhile, 9 other DMUs experienced inefficiency.

Based on the BAZNAS efficiency score in this study, BAZNAS obtained efficient results and was the best DMU. These results can be compared with research by Syaifuddin (2019) which shows that BAZNAS obtained an efficient score in 2017. From year to year (2016-2018), BAZNAS has increased efficiency. This is indicated by the efficiency results of $62.1 \%$ in $2016,113 \%$ in 2017 , and $121.4 \%$ in 2018. The management of zakat by BAZNAS was getting better during the observation period. 
In measuring the efficiency of Rumah Zakat, it shows a difference between Hikmah and Shofawati (2020). This is reasonable because of the use of different assumptions. However, the similarity still exists, namely the increase or decrease in the efficiency of Rumah Zakat. Hikmah and Shofawati (2020) show that the efficiency value of Rumah Zakat 2018 is smaller than Rumah Zakat 2017. The same results are shown in this study, Rumah Zakat 2018 experienced a decrease in performance in 2018.

On the other hand, Dompet Dhuafa experienced inefficiency in the year of observation. This result is supported by research by Kurniawan (2019) which shows the efficiency value of Dompet Dhuafa 2016 is $64 \%$ with the same assumptions and orientation. In this study, the efficiency value of Dompet Dhuafa 2016 was 52.6\%. This difference in value can occur because Kurniawan (2019) uses an output variable in the form of total ZISWAF receipts and total ZISWAF disbursements, while in this study using the output variables of the amount zakat collected and the amount zakat distributed. The efficiency value shows that the efficiency of Dompet Dhuafa has continued to decline from 2016 to 2018. The decline in the efficiency value of Dompet Dhuafa from 2016 to 2017 was also shown by Hikmah and Shofawati (2020). Similar to Dompet Dhuafa, YBM PLN also experienced a decrease in the efficiency value during the observation period. The difference lies in 2016 where YBM PLN showed efficient results and was the best DMU.

Besides, this research provides potential improvement value for DMUs that are considered inefficient. Of the 12 DMUs that were observed, 9 DMUs showed inefficiency. Based on the potential improvement value, Zakat Institutions need to increase the amount of zakat collected and the amount of zakat distributed. Or in other words, the cause of inefficiency is also due to a lack of zakat collected and zakat distributed. This inefficiency is supported by research by Ardiani (2019) and Parisi (2017), which show that inefficiency is due to less than optimal distribution of funds, even though the sample and observation period are different. This means that the causes of inefficiency in this study are not only a concern for the observed institutions but also all zakat institutions in Indonesia. This can be related to the function of the zakat institution as an intermediary institution, namely collecting funds and distributing them. By increasing the number of zakat collected, it means that the Zakat Institution also improves the function of the collection, namely coordinating the needs of muzakki in terms of paying zakat. From the total amount of zakat collected, then zakat institutions can manage and allocate appropriately for the interests of mustahiq. Collection and distribution are related. With the amount zakat collected, there will be zakat distributed.

Judging from the observed institution's financial reports, there are periods when there is a surplus of zakat funds. It can be interpreted that in terms of measuring efficiency with the variable amount of funds channeled, the surplus of zakat funds indirectly causes inefficiency. Referring to the potential improvement value, all observed Zakat Institutions must increase the zakat distributed. If we look at the observed Zakat Institution financial statements, there is a surplus of zakat funds either from one period or from the previous period. For example, YBM PLN was efficient in 2016, but in 2017 and 2018 its experienced inefficiency. When viewed from the YBM PLN financial report, the balance of zakat funds (surplus) in 2018 was Rp111.086.133.205 compared to the previous year Rp78.750.191.866. Judging from the potential improvement, the zakat target distributed by YBM PLN in 2018 must increase by $61 \%$ compared to 2017 which only needs to be increased by $19 \%$. The same thing is shown in the financial statements of Rumah Zakat, Dompet 
Dhuafa, and BAZNAS where there is a surplus of zakat funds.

This zakat surplus needs to be a concern for zakat institutions in their function as an intermediary institution. In the context of zakat governance, Saad et al (2017) say that the management of zakat institutions is not achieved at an optimal level if there is a significant surplus of zakat funds. Furthermore, it is said that zakat institutions can make innovations and proper management for the interests of mustahiq in the context of creating welfare. In terms of efficiency, an increase in the amount of output (the amount of zakat collected and zakat distributed) still requires supervision of the use of inputs or costs so that the increase in output can be carried out as efficiently as possible, but still provide optimal results. For this reason, zakat institutions can use various alternative methods that provide an optimal output at an efficient cost.

On the other hand, the cause of the Zakat Institutions inefficiency found in this study was the input variable. The high use of socialization costs is the main cause of inefficiency from the input side. The same results were also found by Al-Ayubi et al. (2018) and Parisi (2017) which measure efficiency in different periods and samples that it is necessary to reduce the cost of socialization. On the other hand, socialization is one of the priority solutions to zakat problems as shown by Afriadi and Sanrego (2016). There is a potential gap and the realization of zakat funds, socialization is important and requires a lot of money. Thus, the Zakat Institution can review its management so that the socialization carried out can have a significant impact on increasing the amount ofzakat collected and zakat distributed so that the costs incurred for the socialization are productive and efficient.

On the other hand, personnel costs also need to be reduced. However, personnel costs are not a major cause of inefficiency. Most zakat institutions have allocated personnel costs appropriately. However, the 2016 BAZNAS Financial Report shows the need to reduce personnel costs. When salary or personnel costs cannot be done because it is amil's right as one of the ashnaf and is also a reward for his performance in managing zakat, then what needs to be considered is how the fixed costs can produce maximum output. In this case, the quality of personnel needs to be improved so that efficiency can be achieved. This is also conveyed by Rustyani and Rosyidi (2018) who say that their attention is not to minimize costs but to manage cost efficiently, so that expenses are not in vain. Meanwhile, the reduction in operational costs is shown by the 2017 YBM PLN Financial Statements and 2018 PLN YBM.

Meanwhile, the sensitivity analysis by eliminating one of the output variables shows that the efficiency value is sensitive to the variable amount of zakat collected with changes in value at 8 DMU and sensitive to the variable amount of zakat collected. Which is sensitive in the variable of zakat distributed with changes in value at 7 DMU. These variables both affect increasing efficiency, with the greatest influence being the variable zakat collected. The increase in zakat collected and zakat distributed must go hand in hand as a step to create welfare through the proper distribution of zakat on the zakat funds that have been collected.

In the digital era, technology has been implemented in the Zakat Institution because it can provide convenience and fast access in managing zakat. Also, the use of technology supports the efficiency, transparency, and accountability of zakat institutions (Puskas BAZNAS, 2020). Moreover, (Yolanda et al., 2020) show that the better adoption of technology can increase good amil governance practice. In an effort to increase the amount off zakat collected and the amount of zakat distributed while maintaining the use of 
inputs, the application of technology can be improved. For example, BAZNAS implemented technology in 2016 and the number of collections increased by $16 \%$ in 2017 (Puskas BAZNAS, 2020). In this study, BAZNAS in 2017 obtained efficient results. Both BAZNAS, Rumah Zakat, Dompet Dhuafa, and YBM PLN have implemented technology by involving internal and external platforms.

There are inefficiencies caused by the high cost of personnel, so in the application of technology, the institution needs to ensure that the service to pay zakat on digital channels is adequate and Amil is able to operate, so that in the collection and distribution process, Amil can provide services that make it easier for muzakki to pay zakat and convenience zakat distribution for mustahiq. Meanwhile, due to the high or not optimal cost of socialization, zakat institutions can take advantage of digital technology in socialization such as socialization on social media.

Technology provide benefits in increasing the amount of zakat collected. Currently, the Zakat Institution such as BAZNAS uses e-commerce, e-wallets, collaborations with various companies such as Gojek, OVO, and other fintech companies. The application of such technologies makes paying zakat easier, and it is also a means of socializing, especially for the millennial generation. For that, the improvisation of input and output aimed at achieving efficiency, technological innovation can be developed and improved by zakat institutions (Hudaefi et al., 2020).

The application and improvement of the use of technology in the Zakat Institution with the aim of efficiency is also supported by research by Wahab and Rahman (2011) which states that based on theory, technology is important in improving the level of efficiency. Meanwhile, Rachman and Nur Salam
(2018), and Friantoro and Zaki (2019) state that technology is needed in terms of collecting and distributing zakat. This is related to the sensitivity analysis which shows that the efficiency value is sensitive to the variable of the amount of zakat collected and zakat distributed.

Although the value of efficiency in this study is not an absolute result, the value of super efficiency, potential improvement, and sensitivity analysis presented can be of mutual concern so that zakat management can be optimal and following Law No. 23 of 2011 that the management of zakat effectively and efficiently can run as it should.

\section{CONCLUSION}

This research produces several findings, namely the highest efficiency value is in the 2016 YBM PLN Report, the second BAZNAS 2018, the third 2017 BAZNAS, the fourth 2016 PLN YBM, the fifth 2018 Zakat Houses, the six Zakat Houses 2017, the seventh 2016 Zakat Houses, the 2018 PLN YBM 2018, ninth BAZNAS 2016, tenth Dompet Dhuafa 2016, eleventh Dompet Dhuafa 2017, twelfth Dompet Dhuafa 2018. Overall, of the 12 DMUs observed, 3 DMUs were efficient while 9 other DMUs experienced inefficiency. Zakat institutions need to improvise inputs and outputs so that zakat management runs efficiently under Law no. 23 of 2011.

Meanwhile, the potential improvement value of the inefficiency DMU shows the need for an increase in the receipt and distribution of zakat and a reduction in the cost of socialization so that the increase in output must still pay attention to the use of inputs. Meanwhile, the sensitivity analysis shows that the efficiency value is very sensitive to the output collected. The difference of 1 DMU on the results of the sensitivity analysis does not indicate that the variable amounts of zakat distributed can be ignored. Zakat 
collected and zakat distributed are interrelated in the context of creating welfare.

In the digital era, the application of technology can be improved to overcome cost inefficiencies and to increase the amount of zakat collected and the amount of zakat distributed. The use of technology supports the efficiency of zakat institutions and provides great benefits in the management of zakat. The efficiency value generated in this study is not absolute efficiency. However, it remains a common concern in terms of managing zakat effectively and efficiently as described in Law no. 23 of 2011. Zakat Institutions need to conduct regular efficiency evaluations so that the allocation of funds is right and on target with improvisation on inputs and outputs.

\section{ACKNOWLEDGEMENT}

The authors would like to appreciate the Research and Innovation Center of Universitas Airlangga for financial support in writing this research. The authors would like to thank representatives of zakat Institutions, practitioners, academics, zakat associations, and regulators for their support and participation in the completion of this research.

\section{REFERENCES}

Adiwijaya, Z. A., \& Suprianto, E. (2020). Good Governance of Zakat Institutions: A Literature Review. Journal of Southwest Jiaotong University, 55(2), 1-7. https://doi.org/10.35741/issn.02582724.55.2.38

Afriadi, F., \& Sanrego, yulizar d. (2016). Mengurai Permasalahan Distribusi Zakat Kepada Fakir Miskin: Pengalaman Organisasi Pengelola Zakat Baznaz, Dompet Dhuafa, Dan Lazizmu. Jurnal Madania, 20(1), 2336. https://doi.org/10.29300/madania.v20 i1.83

Al-Ayubi, S., . A., \& Possumah, B. T. (2018). Examining the Efficiency of Zakat Management: Indonesian Zakat Institutions Experiences. International Journal of Zakat, 3(1), 37-55. https://doi.org/10.37706/ijaz.v3i1.66

Ali, K. M., Amalia, N. N., \& Ayyubi, S. El. (2016). Perbandingan Zakat Produktif dan Zakat Konsumtif dalam Meningkatkan Kesejahteraan Mustahik. Jurnal Al-Muzara'ah, 4(1), 19-32.

Andersen, P., \& Petersen, N. C. (1993). A Procedure for Ranking Efficient Units in Data Envelopment Analysis. Management Science, 39(10), 12611264.

https://doi.org/10.1287/mnsc.39.10.12 61

Ardiani, N. (2019). the Efficiency of Zakat Collection and Distribution: Evidence From Data Envelopment Analysis. AlUqud: Journal of Islamic Economics, 3(1), 54. https://doi.org/10.26740/aluqud.v3n1.p54-69

Banker, R. D., Charnes, A., \& Cooper, W. W. (1984). SOME MODELS FOR ESTIMATING TECHNICAL AND SCALE INEFFICIENCIES IN DATA ENVELOPMENT ANALYSIS. Management Science. https://doi.org/10.1287/mnsc.30.9.107 8

Budiantoro, R. A., Luthfi, F., \& Herianingrum, S. (2018). Measuring the Efficiency of BAZNAS in Managing Zakat Funds with Stochastic Frontier Approach Analysis, 2002-2016. International Journal of Zakat, 3(1), 89-107. https://doi.org/10.37706/ijaz.v3i1.70

Chapra, U. (1992). Islam and the Economic Challenge. In Review of Islamic Economics.

Charnes, A., Cooper, W. W., \& Rhodes, E. (1978). Measuring the efficiency of decision making units. European Journal of Operational Research. 
https://doi.org/10.1016/0377-

2217(78)90138-8

Friantoro, D., \& Zaki, K. (2019). Do We Need Financial Technology for Collecting Zakat? International Conference of Zakat. https://doi.org/10.37706/iconz.2018.1 33

Hikmah, I. F., \& Shofawati, A. (2020). Analisis Efisiensi 7 Organisasi Pengelola Zakat (OPZ) Nasional Menggunakan Data Envelopment Analysis (DEA). Jurnal Ekonomi Syariah Teori Dan Terapan, 7(6), 1178-1192.

https://doi.org/10.20473/vol7iss20206 pp1178-1192

Hudaefi, F. A., Zaenal, M. H., Farchatunnisa, H., \& Junari, U. L. (2020). How Does Zakat Institution Respond To Fintech? Evidence From BAZNAS Indonesia. International Journal of Zakat and Islamic Philantrhropy, 2(1), 32-40. journal.zakatkedah.com.my

Johari, F., Fahme Mohd Ali, A., binti Mohd Noor, Z., Ridhwan Ab Aziz, M., \& Faisol Ibrahim, M. (2013). Impact of Zakat Distribution on Poor and Needy Recipients: An Analysis in Kelantan, Malaysia. Australian Journal of Basic and Applied Sciences Malaysia. Aust. J. Basic \& Appl. Sci.

Kurniawan, R. (2019). Determinants of Efficiency of Zakat Institutions in Indonesia: Two-Stage Data Envelopment Analysis Approach. International Conference of Zakat. https://doi.org/10.37706/iconz.2018.1 27

Nurzaman, M. S. (2017). The Impact of Zakat Programs from Human Development Perspectives: An Empirical Evaluation. In Financial Inclusion and Poverty Alleviation. https://doi.org/10.1007/978-3-31969799-4_7

Parisi, S. Al. (2017). Tingkat Efisiensi dan Produktivitas Lembaga Zakat di Indonesia. Esensi, 7(1). https://doi.org/10.15408/ess.v7i1.368 7

Puskas BAZNAS. (2020). Outlook Zakat Indonesia 2020. In Baznas.

Rachman, M. A., \& Nur Salam, A. (2018). The Reinforcement of Zakat Management through Financial Technology Systems. International Journal of Zakat, 3(1), 57-69. https://doi.org/10.37706/ijaz.v3i1.68

Razak, S. H. A. (2020). Zakat and waqf as instrument of Islamic wealth in poverty alleviation and redistribution: Case of Malaysia. International Journal of Sociology and Social Policy, 40(3-4), 249-266. https://doi.org/10.1108/IJSSP-112018-0208

Rustyani, S., \& Rosyidi, S. (2018). Measurement of Efficiency and Productivity of Zakat Institutions in Indonesia using Data Envelopment Analysis and the Malmquist Productivity Index. International Journal of Zakat, 3(3), 69-82. https://doi.org/10.37706/ijaz.v3i3.98

Rusydiana, A. S., \& Al Farisi, S. (2016). The Efficiency of Zakah Institutions Using Data Envelopment Analysis. Al-Iqtishad: Journal of Islamic Economics, 8(2), 213-226. https://doi.org/10.15408/aiq.v8i2.287 6

Rusydiana, A. S., \& Widiastuti, T. (2018). Technological and Efficiency Change on Zakat Organization: Evidence in Indonesia. International Conference of Zakat 2018, 1-11. https://www.iconzbaznas.com/submis sion/index.php/proceedings/article/vie $\mathrm{w} / 113 / 60$

Ruysdiana, A. S., \& Hasib, F. F. (2020). Super Efisiensi dan Analisis Sensitivitas DEA: Aplikasi Pada Bank Umum Syariah Di Indonesia. Amwaluna: Jurnal Ekonomi Dan Keuangan Syariah, 4(1), 41-54. https://doi.org/10.1017/CBO9781107 415324.004

Saad, R. A. J., Idris, K. M., Shaari, H., 
Sawandi, N., \& Derashid, C. (2017). Governance of non-profit organizations: A case of zakat institutions in Malaysia. International Journal of Economic Research, 14(16), 253-265.

Sari, D. F., Beik, I. S., \& Rindayati, W. (2019). Investigating the Impact of Zakat on Poverty Alleviation : A Case from West Sumatra, Indonesia. International Journal of Zakat, 4(2), $1-12$.

https://doi.org/10.37706/ijaz.v4i2.180

Syaifuddin, T. (2019). Implementation of Data Envelopment Analysis (DEA) in Measuring the Efficiency Zakat Fund Management. Indonesian Journal of Islamic Economic Research, 1(2), 5866.

Wahab, N. A., \& Rahman, abdul rahim abdul. (2011). A framework to analyse the efficiency and governance of zakat institutions. Journal of Islamic Accounting and Business Research, 2(1), 43-62. https://doi.org/10.1108/17590811111 129508

Wahab, N. A., Rahman, A., \& Rahim, A. (2012). Efficiency of zakat institutions in Malaysia: An application of data envelopment analysis. Journal of Economic Cooperation and Development.

Wahid, H., Ahmad, S., \& Abdul Kader, R. (2009). Pengagihan zakat oleh institusi zakat kepada lapan asnaf: Kajian di Malaysia. Seminar Kebangsaan Ekonomi Islam 2008/09 Pada 10-11 Februari 2009 Di APIUM.

Yolanda, F., Zaenal, M. H., \& Pramono, S. E. (2020). The Effect of Internal Control, Information Technology and Audit on Good Amil Governance Practices. International Journal of Zakat, 5(2), 67-82. https://doi.org/10.37706/ijaz.v5i2.223
Nikmatul Atiya

Department of Islamic Economics, Faculty of Economics and Business, Universitas Airlangga nikmatul.atiya-2017@feb.unair.ac.id

Tika Widiastuti

Department of Islamic Economics, Faculty of Economics and Business, Universitas Airlangga

tika.widiastuti@feb.unair.ac.id

Eko Fajar Cahyono

Department of Islamic Economics, Faculty of Economics and Business, Universitas Airlangga

ekofajarc@feb.unair.ac.id

Siti Zulaikha

Department of Islamic Economics, Faculty of Economics and Business, Universitas Airlangga

siti-z@feb.unair.ac.id

Imron Mawardi

Department of Islamic Economics, Faculty of Economics and Business, Universitas Airlangga

ronmawardi@feb.unair.ac.id 
International Journal of Zakat Vol. 5(3) 2020 